\title{
PENGARUH KONSENTRASI DAN SUHU LARUTAN OSMOTIK TERHADAP PENYUSUTAN VOLUME, KEKERASAN DAN WARNA PADA BUAH NAGA
}

\section{EFFECT OF CONCENTRATION AND OSMOTIC SOLUTION TEMPERATURE ON SHRINKAGE, HARDNESS AND COLORS IN DRAGON FRUIT}

\author{
Spetriani $^{1 *}$, Siti Fathurahmi ${ }^{1}$ \\ ${ }^{1}$ Program Studi Teknologi Hasil Pertanian, Fakultas Pertanian, Universitas Alkhairaat \\ Jl. Diponegoro No. 39 Palu 94221, Sulawesi Tengah, Indonesia
}

\begin{abstract}
ABSTRAK
Dehidrasi osmotik adalah salah satu metode dalam pembuatan pangan semi basah. Dehidrasi osmotik dilakukan dengan cara merendam bahan ke dalam larutan osmotik berupa larutan gula. Tujuan penelitian ini adalah untuk mengkaji pengaruh perlakuan konsentrasi larutan osmotik dan suhu larutan osmotik terhadap penyusutan volume, kekerasan, dan perubahan warna yang terjadi pada buah naga selama proses dehidrasi osmotik. Buah naga direndam dalam larutan osmotik dengan variasi konsentrasi larutan 30 ${ }^{\circ}$ Briks, $50{ }^{\circ}$ Briks, dan $70{ }^{\circ}$ Briks dan suhu larutan $30{ }^{\circ} \mathrm{C}, 40{ }^{\circ} \mathrm{C}$, dan $50{ }^{\circ} \mathrm{C}$. Nilai rata-rata penyusutan volume terbesar hingga terkecil berturut-turut ada pada perlakuan $70^{\circ}$ briks, $50{ }^{\circ} \mathrm{briks}$, dan $30^{\circ} \mathrm{briks}$. Tingkat kekerasan bahan selama dehidrasi osmotik paling rendah terdapat pada perlakuan $70{ }^{\circ}$ Briks dan $50{ }^{\circ} \mathrm{C}$ (B3T3). Nilai diagram CIELAB menunjukkan bahwa rata-rata warna bahan untuk semua perlakuan berada pada kolom warna ungu-merah. Berdasarkan uji anova, perbedaan konsentrasi dan suhu larutan tidak memberikan pengaruh yang nyata terhadap perubahan warna buah naga setelah dehidrasi osmotik.
\end{abstract}

Kata kunci: dehidrasi osmotik; pangan semi basah; penyusutan volume

\begin{abstract}
Osmotic dehydration is one of the methods in making of intermediate moisture food. Osmotic dehydration is done by immersing the material in a osmotic solution in the form of a sugar solution. The purpose of this research is to investigate the effect of concentration and temperature of osmotic solution on volume shrinkage, hardness and color change during the process of osmotic dehydration of dragon fruit.Dragon fruit has been immersed in osmotic solution with varying concentrations of $30^{\circ}$ Brix, 50 ${ }^{\circ}$ Brix, and $70{ }^{\circ}$ Brix and a solution temperature of $30{ }^{\circ} \mathrm{C}, 40{ }^{\circ} \mathrm{C}$, and $50{ }^{\circ} \mathrm{C}$. The average value of the largest to the smallest volume shrinkage in succession is in the treatment of $70^{\circ} \mathrm{Brix}, 50^{\circ} \mathrm{Brix}$, and 30 ${ }^{\circ}$ Brix. The lowest level of material hardness during osmotic dehydration is found in the treatment of 70 ${ }^{\circ}$ Brix and $50^{\circ} \mathrm{C}$ (B3T3). The CIELAB diagram values show that the average color of the material for all treatments is in the purple-red color column. Based on anova test, the difference in concentration and temperature of the solution did not have a significant effect on the discoloration of dragon fruit after osmotic dehydration.
\end{abstract}

Keywords: osmotic dehydration; intermediate moisture food; shrinkage

\section{Pendahuluan}

Buah naga merupakan salah satu jenis buah yang memiliki kadar air cukup tinggi. Kadar air yang tinggi ini menyebabkan aktivitas air meningkat dan mempercepat laju

\footnotetext{
${ }^{*}$ Penulis Korespondensi.

E-mail: spetriani8@gmail.com

Telp: 0852140000429
}

pertumbuhan mikroba. Dibutuhkan penanganan dan pengolahan pasca panen yang baik untuk mencegah kerusakan buah naga sehingga dapat disimpan lama. Salah satu caranya adalah dengan mengolah buah naga menjadi pangan semi basah.

Menurut Taoukis, Breene \& Labuza (1999), pangan semi basah merupakan makanan dengan kadar air yang lebih tinggi dibandingkan dengan makanan kering. Pangan semi basah juga 
dapat dimakan tanpa rehidrasi. Karakteristik produk pangan semi basah memiliki beberapa keunggulan dibandingkan produk kering konvensional atau makanan dengan kadar air tinggi.

Proses pengolahan pangan semi basah menghasilkan produk dengan retensi nutrisi dan kualitas yang lebih tinggi dibandingkan dengan proses lain seperti pengeringan dan proses panas. Pertumbuhan mikroba pada bahan pangan sangat erat hubungannya dengan jumlah kandungan air. Mikroba yang aktif kira-kira mengandung $80 \%$ air. Pertumbuhan mikroba tidak pernah terjadi tanpa adanya air. Kebutuhan mikroba akan air biasanya dinyatakan dalam istilah water activity (aw). Mikroba hanya akan tumbuh pada kisaran $a w$ tertentu. Bahan pangan yang mempunyai $a w$ sekitar 0,7 dianggap sudah cukup baik dan tahan selama penyimpanan (Winarno dan Fardiaz, 1981).

Pangan semi basah merupakan bahan pangan yang mempunyai kadar air antara 10-40\% (Soekarto, 1979). Pangan semi basah memiliki aktifitas air antara 0,65-0,90 yang memungkinkan pertumbuhan bakteri dan khamir menjadi tertekan. Menurut Christine (2008) adanya kondisi aktivitas air yang rendah pada pangan semi basah dapat mencegah pertumbuhan mikroorganisme secara efektif sehingga memiliki daya awet yang cukup lama. Selain itu, daya awet pada pangan semi basah juga sangat tergantung dari komposisi bahan penyusun, cara pengolahan, kemasan yang digunakan, serta kandungan zat pengawet.

Proses pembuatan pangan semi basah terbagi menjadi beberapa kategori. Salah satunya adalah melalui dehidrasi osmotik (Christine, 2008). Dehidrasi osmotik dilakukan dengan cara merendam produk ke dalam larutan gula, larutan garam, sorbitol, gliserol, dan sebagainya untuk menurunkan aw. Adanya perbedaan tekanan osmosis menyebabkan air berdifusi keluar dari bahan dan larutan osmotik akan berdifusi ke dalam bahan. Proses dehidrasi osmosis digunakan untuk perlakuan pengeringan awal yang dapat menurunkan kadar air bahan sampai $50 \%$ dari kadar air awal bahan (Karathanos, Kostaropoulos, \& Saravacos, 1995)

Dehidrasi osmotik pada mangga yang dilakukan oleh Sophia (2011) dapat mempertahankan warna alami potongan mangga selama proses pengeringan. Penelitian yang dilakukan oleh Farah et al., (2015) menyatakan bahwa tidak ada perbedaan yang signifikan pada pengukuran warna antara sampel kulit semangka yang dikeringkan secara osmotik selama 8, 14 dan 20 jam. Sedangkan Mayor, Moreira, \& Sereno (2011) menjelaskan bahwa terjadi penurunan secara non-linear antara penyusutan volume (shrinkage) dengan kadar air bahan baik pada proses dehidrasi osmotik maupun pengeringan udara.

Tujuan penelitian ini adalah untuk mengkaji pengaruh perlakuan konsentrasi larutan osmotik dan suhu larutan osmotik terhadap penyusutan volume (shrinkage), kekerasan (hardness), dan perubahan warna pada buah naga selama proses dehidrasi osmotik.

\section{Metode penelitian}

Penelitian ini dilaksanakan pada Maret 2015 di Laboratorium Teknik Pangan dan Pascapanen Fakultas Teknologi Pertanian, UGM, Yogyakarta. Bahan yang digunakan pada penelitian adalah buah naga, aquades dan gula pasir. Alat yang digunakan adalah waterbath (Neslab instrument, Inc. Newington, NH 03801 U.S.A) drying oven (Memmert, Type UM 400), penetrometer, timbangan analitik (Shimadzu, Type AUW220), colorimeter, termokopel, jangka sorong, penjepit cawan, tray, desikator, gelas ukur, dan pinset.

\section{Analisa Data}

Rancangan percobaan yang digunakan dalam penelitian ini adalah rancangan faktorial dengan dua faktor yang masing-masing terdiri atas 3 taraf dengan 3 kali ulangan. Dua faktor tersebut adalah konsentrasi larutan osmotik dan suhu larutan osmotik. Taraf konsentrasi larutan osmotik yang digunakan yaitu konsentrasi 30 ${ }^{\circ}$ Briks, $50{ }^{\circ} \mathrm{Briks}$, dan $70{ }^{\circ} \mathrm{Briks}$ dan taraf untuk suhu larutan osmotik yaitu suhu $30^{\circ} \mathrm{C}, 40^{\circ} \mathrm{C}$, dan $50{ }^{\circ} \mathrm{C}$. Jumlah keseluruhan perlakuan adalah 9 perlakuan dengan kombinasi disajikan pada Tabel 1.

Tabel 1. Jenis Perlakuan, kombinasi dan notasi perlakuan

\begin{tabular}{cccc}
\hline Konsentrasi & \multicolumn{3}{c}{ Suhu larutan (T) } \\
\cline { 2 - 4 } larutan (B) & $30{ }^{\circ} \mathrm{C}$ & $40{ }^{\circ} \mathrm{C}$ & $50{ }^{\circ} \mathrm{C}$ \\
\hline $30{ }^{\circ} \mathrm{Briks}$ & $\mathrm{B} 1 \mathrm{~T} 1$ & $\mathrm{~B} 1 \mathrm{~T} 2$ & $\mathrm{~B} 1 \mathrm{~T} 3$ \\
$50{ }^{\circ} \mathrm{Briks}$ & $\mathrm{B} 2 \mathrm{~T} 1$ & $\mathrm{~B} 2 \mathrm{~T} 2$ & $\mathrm{~B} 2 \mathrm{~T} 3$ \\
$70{ }^{\circ} \mathrm{Briks}$ & $\mathrm{B} 3 \mathrm{~T} 1$ & $\mathrm{~B} 3 \mathrm{~T} 2$ & $\mathrm{~B} 3 \mathrm{~T} 3$ \\
\hline
\end{tabular}


Analisis statistik yang digunakan dalam penelitian adalah analisis regresi serta uji Analysis of Variance (ANOVA) pada taraf nyata $5 \%$ dan apabila terdapat pengaruh perlakuan, maka akan dilanjut dengan uji DMRT menggunakan SPSS.

Prosedur penelitian diawali dengan pembuatan larutan osmotik dengan cara melarutkan gula (sukrosa) dalam sejumlah aquades hingga mencapai konsentrasi yang diperlukan. Larutan osmotik dalam gelas beker kemudian dimasukkan ke dalam waterbath sesuai dengan suhu yang ditentukan. Setelah itu buah naga dicuci bersih, dikupas dan dipotong dengan ukuran panjang $25 \mathrm{~mm}$, lebar $40 \mathrm{~mm}$, dan tebal 8 $\mathrm{mm}$. Potongan sampel buah naga direndam dalam larutan osmotik dan dilakukan pengukuran dimensi dan tekstur sampel dengan selang waktu pengukuran setiap 30 menit selama 8 jam. Sedang untuk perubahan warna dilakukan pengukuran sebelum dan sesudah perlakuan dehidrasi osmotik.

Penyusutan volume bahan dihitung dengan cara mengukur dimensi bahan, yaitu panjang, lebar, dan tebal bahan. Penyusutan volume dinyatakan dalam persentase dan dapat dihitung menggunakan persamaan

$$
V_{R}(\%)=-\frac{V_{t}-V_{0}}{V_{0}} \times 100 \%
$$

Dimana : $V_{R}=$ penyusutan volume $(\%)$

$V_{t}=$ volume sampel pada waktu $\mathrm{t}\left(\mathrm{cm}^{3}\right)$

$V_{0}=$ volume sampel pada waktu 0 menit $\left(\mathrm{cm}^{3}\right)$

Kekerasan (hardness) bahan diukur menggunakan penetrometer dengan cara menekan ujung penetrometer ke sebidang bahan kemudian membaca nilai yang ditunjukkan oleh jarum penunjuk nilai.

Warna buah naga diukur menggunakan colorimeter untuk menentukan $L^{*}$ (Lightness), $a^{*}$ (redness) dan $b^{*}$ (yellowness). Nilai $L$ menunjukkan nilai kecerahan. Nilai $L=0$ untuk warna hitam dan 100 untuk warna putih. Nilai $a$ menunjukkan warna kromatik campuran merah hijau yang nilainya bergerak dari positif $(0-100)$ untuk warna merah sampai negatif (0-80) untuk warna hijau. Nilai $b$ menunjukkan warna kromatik campuran biru kuning yang nilainya bergerak dari positif (0-70) untuk warna kuning sampai negatif (0-70) untuk warna biru. Peralatan yang digunakan adalah colorimeter yang dikalibrasi dengan standar warna putih $\left(\mathrm{L}^{*}=\right.$ 97,71; $a^{*}=-0,59 ;$ dan $\left.b^{*}=2,31\right)$. Total perbedaan warna dihitung dengan menggunakan persamaan berikut.

$$
\Delta E=\sqrt{\Delta L *^{2}+\Delta a *^{2} \Delta b *^{2}}
$$

Dari nilai $a$ dan $b$ yang diperoleh dapat dihitung chroma dengan menggunakan persamaa berikut.

$$
C^{2}=\sqrt{\left(a^{*}\right)^{2}+\left(b^{*}\right)^{2}}
$$

Sedangkan hue angle $(H)$ dihitung dengan persamaan berikut.

$$
H=\operatorname{Tan}^{-1}\left(\frac{b^{*}}{a^{*}}\right) \times 57,3
$$

\section{Pembahasan}

\section{Penyusutan volume (shrinkage)}

Berdasarkan Gambar 1 penyusutan volume pada bahan meningkat terhadap waktu. Sejalan dengan penurunan kadar air, semakin besar penurunan kadar air bahan semakin besar pula penyusutan volume yang terjadi. Mavroudis, Gekas \& Lazarides (1997) menyatakan bahwa penyusutan bahan pada saat dehidrasi osmotik tidak dapat dihindari karena adanya proses keluarnya air dari bahan. Pada saat air keluar dari bahan terjadi ketidakseimbangan antara tekanan di dalam bahan dengan di luar bahan yang menimbulkan kontraksi dan memicu terjadinya penyusutan baik pada massa dan volume serta perubahan bentuk bahan.

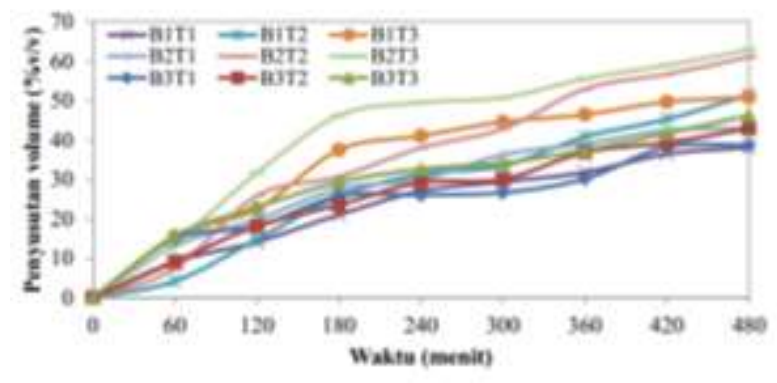

Gambar 1. Penyusutan volume bahan selama proses dehidrasi osmotik

Nilai konstanta laju penurunan volume pada tiap perlakuan dapat dilihat pada Tabel 2 . Nilai konstanta tertinggi ada pada perlakuan B3T3 $\left(70{ }^{\circ}\right.$ Briks dan $50{ }^{\circ} \mathrm{C}$ ). Nilai konstanta ini menunjukkan tingkat penyusutan volume yang terjadi pada bahan. Semakin besar nilai konstanta semakin cepat pula volume bahan menyusut. Analisis gambar menunjukkan bahwa penyusutan volume sampel selama dehidrasi osmotik adalah isotropik (Mayor et al., 2011) 
Tabel 2. Nilai konstanta laju penurunan volume pada tiap perlakuan

\begin{tabular}{cccc}
\hline & \multicolumn{3}{c}{ Suhu larutan (T) } \\
\cline { 2 - 4 } $\begin{array}{c}\text { Konsentrasi } \\
\text { larutan (B) }\end{array}$ & $30{ }^{\circ} \mathrm{C}$ & $40{ }^{\circ} \mathrm{C}$ & $50{ }^{\circ} \mathrm{C}$ \\
\hline $30{ }^{\circ}$ Briks & 0.0011 & 0.0014 & 0.0017 \\
$50{ }^{\circ}$ Briks & 0.0014 & 0.0020 & 0.0023 \\
$70{ }^{\circ}$ Briks & 0.0018 & 0.0022 & 0.0025 \\
\hline
\end{tabular}

Penyusutan volume di menit terakhir (ke480) untuk semua perlakuan dianalisa secara statistik dengan uji anova dua arah. Berdasarkan analisis statistik faktor konsentrasi larutan dan suhu larutan memiliki nilai signifikansi di bawah 0,05 yang berarti bahwa perlakuan tersebut memberikan pengaruh yang signifikan terhadap penyusutan volume yang terjadi pada bahan. Hal ini sejalan dengan penelitian yang dilakukan oleh Fathi, Mohebbi, \& Razavi (2011) yang menyatakan bahwa peningkatan waktu pengeringan dan suhu menyebabkan peningkatan penyusutan volume. Analisis dilanjutkan dengan uji lanjut DMRT yang disajikan pada Tabel 3.

Tabel 3. Hasil uji DMRT pengaruh perlakuan terhadap penyusutan volume

\begin{tabular}{ccccc}
\hline \multirow{2}{*}{ Variasi Perlakuan } & \multicolumn{3}{c}{ Subset } \\
\cline { 3 - 5 } & & 1 & 2 & 3 \\
\hline Konsentrasi & $30^{\circ} \mathrm{Briks}$ & 46.822 & & \\
& $50^{\circ} \mathrm{Briks}$ & & 55.633 & \\
\multirow{4}{*}{ Suhu } & $70^{\circ} \mathrm{Briks}$ & & & 62.489 \\
& $30^{\circ} \mathrm{C}$ & 45.522 & & \\
& $40^{\circ} \mathrm{C}$ & & 58.511 & \\
& $50^{\circ} \mathrm{C}$ & & 60.911 & \\
\hline
\end{tabular}

Berdasarkan hasil uji DMRT untuk perlakuan konsentrasi larutan diperoleh nilai yang berbeda nyata antara masing-masing taraf konsentrasi yang digunakan pada penelitian. Nilai rata-rata penyusutan volume terbesar hingga terkecil berturut-turut ada pada perlakuan 70 'briks, $50{ }^{\circ}$ briks, dan $30^{\circ}$ briks. Hasil uji DMRT untuk faktor suhu diperoleh perlakuan suhu $30{ }^{\circ} \mathrm{C}$ berbeda nyata dengan suhu $40{ }^{\circ} \mathrm{C}$ dan $50{ }^{\circ} \mathrm{C}$. Nilai rata-rata terkecil penyusutan volume terjadi pada suhu $30{ }^{\circ} \mathrm{C}$. Penyusutan volume ini berbanding lurus dengan perubahan kadar air. Semakin besar konsentrasi larutan dan suhu larutan yang digunakan pada proses dehidrasi osmotik, semakin besar penurunan kadar air, dan semakin besar pula penyusutan volume.

\section{Kekerasan (hardness)}

Pada beberapa bahan pangan olahan seperti bahan hasil pengeringan, tekstur juga merupakan salah satu parameter penerimaan konsumen terhadap produk. Secara umum, nilai kekerasan pada bahan yang mengalami dehidrasi osmotik menurun terhadap waktu. Semakin lama bahan direndam dalam larutan osmotik semakin kecil nilai tekan pada bahan. Penurunan nilai hardness bahan untuk setiap perlakuan selama proses dehidrasi osmotik dapat dilihat pada Gambar 2.

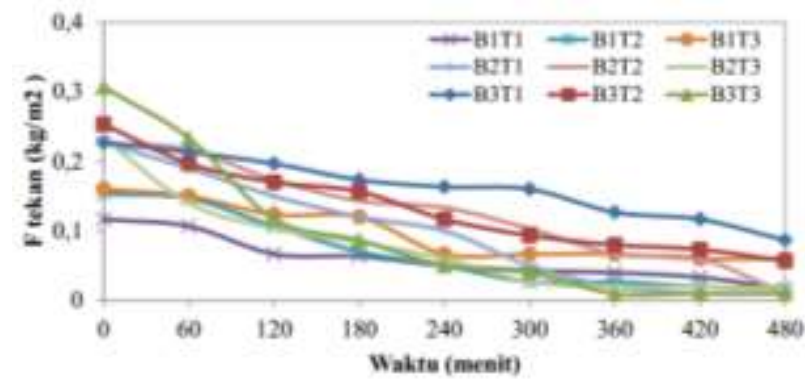

Gambar 2. Penurunan nilai kekerasan bahan selama proses dehidrasi osmotik

Pada Tabel 4 berikut ditampilkan konstanta laju penurunan hardness akibat dehidrasi osmotik pada masing-masing perlakuan. Perlakuan B3T3 $\left(70{ }^{\circ}\right.$ Briks dan $50{ }^{\circ} \mathrm{C}$ ) memperoleh nilai konstanta yang lebih besar dibandingkan dengan perlakuan lainnya. Hal ini disebabkan suhu yang digunakan pada perlakuan tersebut cukup tinggi sehingga mengakibatkan terjadinya pelunakan pada bahan.

Tabel 4. Nilai konstanta laju penurunan kekerasan pada tiap perlakuan

\begin{tabular}{cccc}
\hline \multirow{2}{*}{$\begin{array}{c}\text { Konsentrasi } \\
\text { larutan (B) }\end{array}$} & \multicolumn{3}{c}{ Suhu larutan (T) } \\
\cline { 2 - 4 } & $30{ }^{\circ} \mathrm{C}$ & $40{ }^{\circ} \mathrm{C}$ & $50{ }^{\circ} \mathrm{C}$ \\
\hline $30{ }^{\circ} \mathrm{Briks}$ & 0.0037 & 0.0052 & 0.0043 \\
$50{ }^{\circ} \mathrm{Briks}$ & 0.0061 & 0.0041 & 0.0062 \\
$70{ }^{\circ} \mathrm{Briks}$ & 0.0017 & 0.0032 & 0.0078 \\
\hline
\end{tabular}

Hasil uji anova dua arah menunjukkan nilai signifikansi yang lebih besar dari 0,05 sehingga dapat dikatakan bahwa perbedaan konsentrasi dan suhu larutan berpengaruh signifikan terhadap tingkat tesktur dari bahan. Analisa dilanjutkan dengan uji lanjut DMRT untuk mengetahui perbedaan antara masingmasing taraf perlakuan. Hasil uji lanjut DMRT dapat dilihat pada Tabel 5. Berdasarkan uji DMRT antara kekerasan pada konsentrasi 30 ${ }^{\circ}$ Briks dan $70{ }^{\circ}$ Briks tidak berbeda nyata satu sama lain namun berbeda nyata dengan 
konsentrasi $50{ }^{\circ}$ Briks. Sedangkan kekerasan pada suhu $30{ }^{\circ} \mathrm{C}$ dan $40{ }^{\circ} \mathrm{C}$ dinyatakan berbeda nyata dengan kekerasan pada suhu $50{ }^{\circ} \mathrm{C}$.

Tabel 5. Hasil uji DMRT untuk konstanta penurunan kekerasan

\begin{tabular}{|c|c|c|c|}
\hline \multirow{2}{*}{\multicolumn{2}{|c|}{ Variasi Perlakuan }} & \multicolumn{2}{|c|}{ Subset } \\
\hline & & 1 & 2 \\
\hline \multirow[t]{2}{*}{ Konsentrasi } & $30^{\circ}$ Briks & 0.0044 & \\
\hline & $50^{\circ}$ Briks & & 0.0054 \\
\hline \multirow{4}{*}{ Suhu } & $70^{\circ}$ Briks & 0.0042 & \\
\hline & $30^{\circ} \mathrm{C}$ & 0.0038 & \\
\hline & $40^{\circ} \mathrm{C}$ & 0.0042 & \\
\hline & $50^{\circ} \mathrm{C}$ & & 0.0061 \\
\hline
\end{tabular}

\section{Warna}

Warna merupakan salah satu sifat fisik yang berpengaruh pertama kali terhadap tingkat penerimaan konsumen pada suatu produk pangan. Perubahan warna dapat terjadi pada bahan pangan yang mengalami suatu proses tertentu seperti pengeringan. Pra-perlakuan dehidrasi osmotik yang diterapkan pada pengeringan buah-buahan dapat mempertahankan warna bahan dan mencegah kerusakan warna serta mengurangi kapasitas penyerapan produk dehidrasi (Krokida, Karathanos, \& Maroulis, 2000). Pengukuran warna pada penelitian ini dilakukan sebelum dan sesudah proses dehidrasi osmotik. Dari Gambar 3 hingga 5 berdasarkan diagram CIELAB terlihat rata-rata warna bahan berada pada kolom warna violet-red dan tidak terjadi perubahan yang besar antar perlakuan.

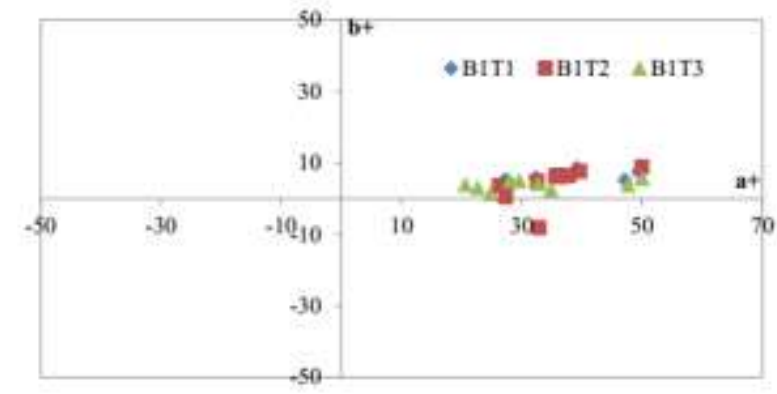

Gambar 3. Posisi nilai $a^{*}$ dan $b^{*}$ bahan setelah dehidrasi osmotik ( $30{ }^{\circ}$ Briks)

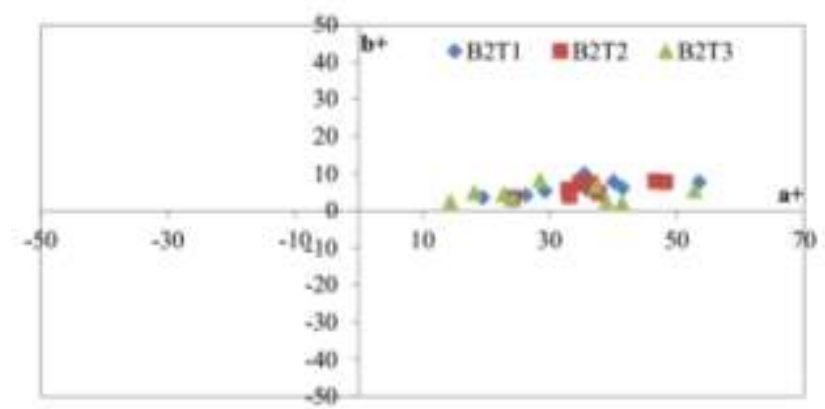

Gambar 4. Posisi nilai $\mathrm{a}^{*}$ dan $\mathrm{b}^{*}$ bahan setelah dehidrasi osmotik $\left(50{ }^{\circ}\right.$ Briks $)$

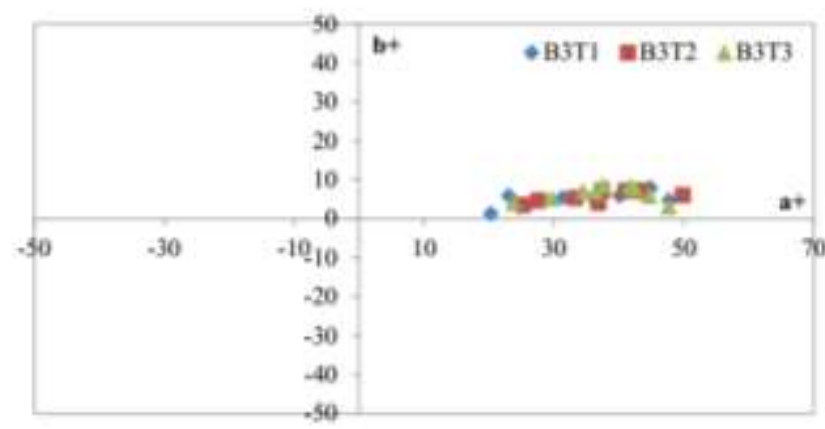

Gambar 5. Posisi nilai $a^{*}$ dan $b^{*}$ bahan setelah dehidrasi osmotik $\left(70^{\circ}\right.$ Briks $)$

Hasil uji anova dua arah nilai signifikansi yang lebih besar dari 0.05. dari hasil tersebut dapat dikatakan bahwa baik variasi larutan osmotik maupun variasi suhu tidak memberikan pengaruh yang signifikan terhadap warna bahan setelah dehidrasi osmotik.

\section{Kesimpulan}

Perlakuan perbedaan konsentrasi larutan dan suhu larutan memberikan pengaruh terhadap penyusutan volume dan tingkat kekerasan bahan. Semakin tinggi konsentrasi dan suhu larutan osmotik, semakin besar penyusutan volume yang terjadi. Tingkat kekerasan buah naga selama proses dehidrasi osmotik menurun terhadap waktu. Pada perubahan warna buah naga, tidak terdapat perbedaan warna buah antara perlakuan yang diberikan.

\section{Daftar Pustaka}

Christine. (2008). Pengembangan pangan semi basah berbasis daging sebagai alternatif pangan darurat. Skripsi. Departemen Ilmu dan Teknologi Pangan FTP, IPB, Bogor.

Farah, N., Muhamad, H., Nur, W., Wan, Z., Kormin, S., Mohd, N., \& Ali, M. S. (2015). International Journal of Science and Engineering ( IJSE ) Processing of 
Watermelon Rind Dehydrated Candy. 8(January), 6-9.

Fathi, M., Mohebbi, M., \& Razavi, S. M. A. (2011). Effect of Osmotic Dehydration and Air Drying on Physicochemical Properties of Dried Kiwifruit and Modeling of Dehydration Process Using Neural Network and Genetic Algorithm. Food and Bioprocess Technology. https://doi.org/10.1007/s11947-010-0452-z

Karathanos, V. T., Kostaropoulos, A. E., \& Saravacos, G. D. (1995). Air-drying kinetics of osmotically dehydrated fruits. Drying Technology. https://doi.org/10.1080/073739395089170 36

Krokida, M. K., Karathanos, V. T., \& Maroulis, Z. B. (2000). Effect of osmotic dehydration on color and sorption characteristics of apple and banana. Drying Technology.

https://doi.org/10.1080/073739300089177 45

Mavroudis, N.E., V. Gekas and H.N. Lazarides. (1997). Shrinkage in osmotic dehydration of plant tissues. Proceeding of the second project

workshop,
Process Optimisation and Minimal Processing of Food, Vol.3 : Drying. Warsaw Poland.

Mayor, L., Moreira, R., \& Sereno, A. M. (2011). Shrinkage, density, porosity and shape changes during dehydration of pumpkin (Cucurbita pepo L.) fruits. Journal of Food Engineering, 103(1), 29-37. https://doi.org/10.1016/j.jfoodeng.2010.08. 031

Soekarto S.T. (1979). Air ikatan, penetapan kuantitatif dan penerapannya pada stabilitas pangan dan disain pangan semi basah. Departemen Teknologi Hasil Pertanian, Fatemeta IPB, Bogor.

Sophia, M.. (2008). Karakteristik pengeringan dan evaluasi mutu pada potongan mangga varietas arumanis dengan praperlakuan dehidrasi osmotik. Skripsi. Departemen Teknik Pertanian FTP, IPB, Bogor.

Taoukis PS, Breene WM, Labuza TP. (1999). Intermediate Moisture Food. (P. 14,969) Minnesota: Departement of Food Science and Nutrition.

Winarno, F.G., Fardiaz, D. (1981). Pengantar Teknologi Pangan. Jakarta. Gramedia. 